UDC 631.15:332.3

JEL Classification: R52, Q15

DOI: https://doi.org/10.32317/2221-1055.201907092

O.S. KRAMAROV

\title{
Economic incentives for the rational use of agricultural land
}

\begin{abstract}
Purpose of the article is to explore the features and necessary prerequisites of economic incentives for the rational use of agricultural land.

Research methods. In the research process the following scientific methods were used: statistical and economic (for calculating the amount of land with different inclined steepness), comparative, and calculated. Based on the abstractlogical, systemic and comparative analyzes, were grouped tools that are inherent in modern financial policies for countries with different economic development level for the formation of an economic mechanism for the rational use of agricultural land. Structuring of the main financial instruments and directions for their improvement is feasible using the graphical method and the systematic approach.

Research results. In the research process were highlighted the features of the application of economic incentives for the rational use of agricultural land. The main prerequisites for the rational use and reproduction of land resources were analysed.

Elements of scientific novelty. The scientific novelty lies in the defined concept of "economic incentives for the rational land use", systematic study of which creates a methodological basis for substantiating and implementing a coherent system for ensuring the rational use of agricultural land.

Practical significance. In the article were justified proposals for economic promotion of the rational use of agricultural land, as well as criteria and recommendations for the taxation of sloping land. Tabl.: 1. Figs.: 1. Refs.: 26.

Keywords: rational land use; economic incentives; land resources; increase of land fertility; land protection; tax incentives.

Kramarov Oleksandr Serhiiovych - research fellow of the laboratory of economic research, State Institution "Institute of Grain Crops of NAAS" (14, V. Vernadskoho st., Dnipro)

E-mail: askramar@ukr.net

ORCID iD http://orcid.org/0000-0002-0350-6213
\end{abstract}

Scientific problem. Information on the state of soil cover is the basis for the rational use of land resources. The economic basis for the rational use, protection and management of soil quality to ensure sustainable fertility should be a mechanism of economic incentives for the rational use of soil resources, their protection and preservation and reproduction of soil fertility while strengthening economic and legal responsibility for violation of legislation on the protection of agricultural land.

Analysis of recent research and publications. Considerable attention is paid to this issue, as evidenced by regular and numerous publications in scientific journals.

The issues of state regulation of land relations, the agrarian sector of the economy are reflected in the works of scientists such as: D.S. Dobriak [5], V.M. Zaiats [6], Yu.O. Lupenko [18], P.T. Sabluk [16], V.M. Trehobchuk [19], A.M. Treiak [20], M.M. Fedorov [13, 21], I.V. Koshkalda [7 - 9] and others.
Considerable attention was paid by economists-agrarians of the National Research Center "Institute of Agrarian Economics" to developing guidelines for economic incentives for landowners and land users for the rational use and protection of land, in particular by a group of authors headed by M. M. Fedorov [13];

Systematically investigated the problem and proposed criteria for economic incentives for the rational use and protection of land by M.P. Martyniuk. Scientist has analyzed the instrumental base, which is regulated in the domestic legislation and highlighted the components of the economic mechanism to stimulate the rational use and protection of land [12].

Researches of the regulation of relations in the field of agrochemical certification in the formation of sustainable agricultural land use, are the works of I. V. Koshkalda [9]. However, this problem requires more in-depth research and the search for new ways to improve the rational use and protection of land. For this, it is necessary to create independent analytical agrochemical laboratories equipped with the latest equipment in all administrative 
areas of the state, which should be owned by the state and used effectively for monitoring soils, in particular their quality. This, in turn, will make it possible to strengthen the regulatory role of the state, in particular, to control the quality of the soil, which will allow for an effective policy of economic incentives for the reproduction of soil fertility or recovery for its loss.

The study of the economic impact of the state on the regulation of land relations and the formation of basic principles in ensuring the rational use of agricultural lands are reflected in foreign publications and legislative acts: Marian Sling [24], I. Williamson [26] and decisions of the European Parliament [25].

The purpose of the article is to explore the features and necessary prerequisites of economic incentives for the rational use of agricultural land.

Research results. Among various forms of influence on the formation of a model of land relations, which would ensure the rational use of land resources, economic incentives play a key role.

Under the economic incentives for the rational use of agricultural land should be understood a complex socio-economic category associated with the direction of motivational encouragement of land users in the rational use of land, taking into account their spatial position, which would satisfy the needs of society from the land and ensure the restoration of lost soil fertility through direct and indirect incentives.

Economic incentives are understood as an integral part of the economic mechanism of management in the field of environmental management and environmental protection, in particular, the rational use of agricultural land.

In general terms, economic incentives include:

- Taxation (in particular land tax)

- Financial and credit mechanism for the effective use of agricultural land (preferential loans, subsidies, etc.);

- Pricing policy (the use of promotional prices and surcharges on environmentally friendly products, the regulation of prices for primary resources and final products);

- State support for agricultural enterprises (financing measures to improve soil fertility and environmental protection, financing land management, reimbursement of expenses for the purchase of mineral fertilizers, plant protection products, the allocation of additional funds for the production of elite seed production, the provision of financial assistance in the development and development of personal peasant farms, the formation of the insurance system in agriculture, maintaining a stable level in guaranteed purchase prices for all products and raw materials;

- creation of a system of environmental certification;

- formation of a land use market;

- introduction of accelerated depreciation of fixed assets (soil-protective equipment, anti-erosion hydraulic structures);

- licensing of the use of natural resources.

So, incentives in this area can be seen as an incentive to take active steps to comply with and implement environmental legislation and as a reward for the results already achieved. However, it should be noted that economic incentives are necessary not for all economic activities aimed at protecting land resources, but only for those that are essential. For example, it would be pointless to encourage the land user and the owner of the land plot to combat weed, since this is a standard everyday action of the land user and the owner of the land plots, at the same time is his duty. Failure to comply with this measure leads to negative consequences for the relevant subject of land relations, both economic in nature - reduced soil productivity, and consequently, a decrease in yields and profits, and a legal nature - legal liability, especially with regard to littering of the arable soil layer by seeds of quarantine weeds ( for example, Ambrosia artemisiifolia, etc.).

In contrast to incentives in this area, current legislation provides for legal liability, which in this case can be called compulsory incentives. In addition, it should be noted that a combination of measures of economic incentives and responsibility in the use and protection of land, according to Art. 3 of the Law "On State Control of Land Use and Protection" [15], was recognized as one of the basic principles for exercising state control over land use and protection along with such principles as: ensuring the rational use and protection of land as basic national wealth, which is under special state protection; the priority of the requirements of ecological security in the use of land resources over economic interests; full compensation for damage 
caused to the environment as a result of violation of the land legislation of Ukraine. From a conceptual perspective, the improvement of the economic mechanism of extended fertility reproduction of soils and the rational use of agricultural land should be based on certain provisions, the main of which are:

- the output economic prerequisite should be the harmonization of entrepreneurial motivation with the economic interest in introducing soil-protective technologies and projects, because the current practice of agricultural management suggests that most enterprises operate on the principle of "competitiveness in exchange for soil fertility." Therefore, the solution of this dilemma by the harmonious relationship of these motifs is a cornerstone in the formation of an effective economic mechanism [2];

- stimulation of agricultural producers in the field of conservation and efficient use of agricultural land should be implemented through a rational combination of administrative methods of influence (state support, fees for soil quality deterioration, penalties for violating the principles of ecologic land use, monitoring the agrochemical condition of the soil) and economic regulation mechanisms (taxation , pricing, benefits, etc.);

- it is necessary to stimulate only the expanded reproduction of soil fertility, as the main motivating factor for the owner investments and land user to invest additional capital in the preservation and reproduction of soil fertility. Economic incentives should not exceed the size of penalties when changing the agro-ecological assessment of the soil in the direction of increase or decrease;

- the economic mechanism for the rational use of agricultural land should be a regulator of the environmental activities of producers and provide for the strengthening of environmental responsibility;

- stimulating the concentration of land in efficient land users and landowners and ensuring the receipt of funds for financing soil protection activities by paying compensation to those land users whose activities have caused a deterioration in the qualitative and ecological state of the soil.

Formation of a full-fledged system of targeted economic regulation of resource use should be one of the main directions of state policy. According to this, the use of natural resources and ensuring environmental safety should be planned as part of comprehensive programs aimed at achieving a balance between the levels of harmful effects on the environment and its ability to recover [3, p. 328].

The key point in any strategy regarding the development of an economic mechanism for the rational use of agricultural land, which the country chooses is the choice of a conceptual basis for the further development of the economic mechanism of environmental management, provides for the preservation of payments for environmental pollution and natural resources, the formation of a system of financing and crediting environmental protection measures. The Figure shows the leading instruments of the countries of modern financial policy with corresponding improvements that are inherent in them, with the direction of development of the agro-industrial complex, in particular, the formation of a mechanism for the rational use of land.

The most developed countries give preference to state support, by means of regulated subsidization rules that guide the development of agricultural farms. Developing countries are building an economic mechanism based on various tariffs. The least developed countries have a common tax system with corresponding standardized advanced instruments.

In the main economic measures to ensure the development of land relations and the balanced use of land resources are systematized and their impact on the development of land relations with the necessary prerequisites for a balanced use and reproduction of land resources is described. It is necessary to conduct an analysis of the rational use of land resources, since the country continues significant transformation processes in rural production in the absence of proper control over the final results, taking into account the environmental, social and economic efficiency of the final effects of land management. The mechanism of economic incentives for the preservation and improvement of soil fertility of agricultural land is based on the principles of the monetary value of land. The monetary assessment of 1 hectare of land and the dynamics of changes in agrochemical indicators are taken as the basis (primary) basis for calculating the size of economic incentives. The condition for economic incentives is the improvement of all indicators of soil fertility or 
their stabilization, given in the agrochemical passport.

The scale of differentiation of the size of economic incentives for increasing the scoring of the land sets the percentage of economic incentives for increasing the scoring of the earth averages for each interval differentially for every 1 credit score, and the size of the economic incentives is charged with a cumulative total [1, c. 20]. Studies show that the domestic land tax should form a fund for financing land conservation measures and ensure the restoration of soil fertility.

To accumulate financial resources for the recreation of land resources, it is proposed to create a land fund for restoring lost soil fertility. Sources of filling this fund should consist mainly of state subsidies and penalties imposed on land users, which by their actions led to a deterioration in the qualitative composition of land resources. Resources of the fund should be used only for recreation purposes, in particular: stimulation of investment activities aimed at improving land fertility; infrastructure development of specialized institutions that provide land recreation; organization of research on land recreation; improvement and standardization of soil productivity research methods; improvement of methods for the rehabilitation of technologically polluted lands; regulation of methods, technologies and technical means of the organization of biological farming; the implementation of training, retraining and advanced training of personnel for the field of ensuring land fertility; carrying out reclamation, anti-erosion measures for the reproduction of land fertility; construction and reconstruction of land reclamation facilities, engineering land reclamation communications; conducting remediation and prevention of land desertification; monitoring the reproduction of land fertility and the formation of the appropriate information bank of the agrochemical state of the soil [18]. Further studies of financial science in this direction should be based on the improvement of taxation of agricultural land.

Land tax in the state economic regulation of the efficiency of agricultural land use becomes the main tool, although the state has a number of economic regulators at its disposal to regulate land relations. In order for the stimulating role of this tax to be fully revealed, we believe that it is necessary to attach this tax instrument to contour-land rec- lamation planning, as well as ecological and economic crop rotation.

Agrarian science and domestic agricultural practice show that with the help of crop rotation it is possible to dose the production anthropogenic load on agricultural land, thereby achieving the effect of recreating, preserving and improving their qualitative state. Ultimately, the agricultural commodity producer should receive a project that will ensure the rational and efficient use of all lands, create favorable conditions for increasing labor productivity, minimize capital investments, settle the issue of suspending erosion processes, determine the areas of land that are economically efficient and environmentally dangerous [11].

Land tax in the state economic regulation of the efficiency of agricultural land use becomes the main tool, although the state has a number of economic regulators at its disposal to regulate land relations. In order for the stimulating role of this tax to be fully revealed, we believe that it is necessary to tie this tax instrument in contour-landreclamation planning, as well as in ecological and economic crop rotation. The point here is that in the conditions of transition to market conditions of management there arises the need to concentrate growing highly productive crops to produce competitive and environmentally safe products. In crop rotations, farms are grown in most cases, a small set of field crops, and therefore it is quite difficult to place them after good predecessors, since crops return to their former place of cultivation in a year, and much of them are re-grown for 1-2 years, which leads to a significant decrease in crop yield. This negative phenomenon can be avoided by saturating short-crop rotations with various types of intermediate crops (crop, subsowing, post-crop, etc.) using them for fodder or green manure. The most promising direction is the introduction of crop rotations into production with a large set of crops, which differ in their biological characteristics. This is due to the fact that in crop rotation, where cultures alternate with different requirements for soil moisture, nutrients, pathogens, this negative phenomenon is not observed. Crop rotation should include the most productive crops (their varieties and hybrids) that corresponds most closely to the soil and climatic conditions of their growing area. The structure of crop areas of crop rota- 
tion should strictly correspond to the specialization of the farm, which makes it possible to obtain cheap, high-quality and environmentally safe products, as well as control the ratio of perennial grasses and tilled crops as a stabilizing factor in the balance of humus in the soil. According to German scientists (G. Ryubenzam, G. Raue, 1960), one-year use of a layer of perennial grasses accumulates 2-3 t/ha humus in the soil, and under tilled crops as much is lost, therefore alfalfa and sapartsels should be present in crop rotations, which will give the ability to form a positive balance of humus.

If the farms adhere to these requirements, both in terms of compatibility of crop alternation, saturation with intermediate crops, the most rational structure of sown areas, the introduction of perennial grasses in crop rotation, preservation of soil fertility and protection from erosion, then in this case it will provide high yields of all cultivated crops and productivity of crop rotation in general.

Agrarian science and domestic agricultural practice show that with the help of crop rotation it is possible to dose the production anthropogenic load on agricultural land, thereby achieving the effect of reproducing, preserving and improving their qualitative state. Ultimately, the agricultural commodity producer should receive a project that will ensure the rational and efficient use of all lands, create favorable conditions for increasing labor productivity, minimize capital investments, settle the issue of suspending erosion processes, determine the areas of land that are economically inefficient and environmentally dangerous [11].

In our opinion, the project should be made significant changes. They should provide that such projects should be developed and approved by agricultural producers themselves, having in their staff specialists in agronomy or other specialists in agriculture employed on a contractual basis. For the state is fixed only the right to establish crop rotation norms:

- prohibition of the introduction of monoculture;

- determine the percentage of land that should be under cover crops;

- scientifically substantiate the period for the permitted return to the cultural field;

- development of appropriate requirements for crop rotation depending on the angle of inclination of the field, the exposure of the slopes, etc.

That is, for each type of agricultural landscape and soil type, taking into account the peculiarities of the region, at the legislative level there should be a development of requirements for crop rotations, according to which agricultural producers should be provided with tax incentives to encourage them to fulfill these requirements.

It is very important that compliance with the relevant norms of impact on crop rotation occurs not according to the Soviet model, but by economic methods: by means of a differentiated tax burden depending on the ecological and economic substantiation of crop rotation and land improvement, as well as with the development of a subsidy mechanism for returning funds for each hectare following the example of countries of European Community.

For example, in some places, the soil on the slopes may lose partially or even completely humus layer as a result of the development of erosion processes in them. These soils have low fertility and the maintenance of agricultural production on them is associated with additional costs. Therefore, land users of such land should enjoy appropriate benefits. In the Table shows the criterion for granting benefits on land taxation of sloping lands, and land plots with a slope angle of more than seven degrees should be generally removed from crop rotation.

World experience shows that an increase in the efficiency of agriculture is possible only under the condition of intensive use of highly productive soils due to a decrease in investments in unproductive soils.

In countries of European Community, land is not cultivated if one hectare of land does not receive 500 euros of profit. Only with such profitability can we ensure the innovative and investment attractiveness of the industry, return people to the villages to create comfortable living conditions [17, p. 54].

Therefore, an urgent problem is the optimization of the land fund of the country, the reduction of its agricultural development and plowing, which will improve the ecological condition of agricultural forests and intensify production due to the concentration of funds in a smaller area [14]. 


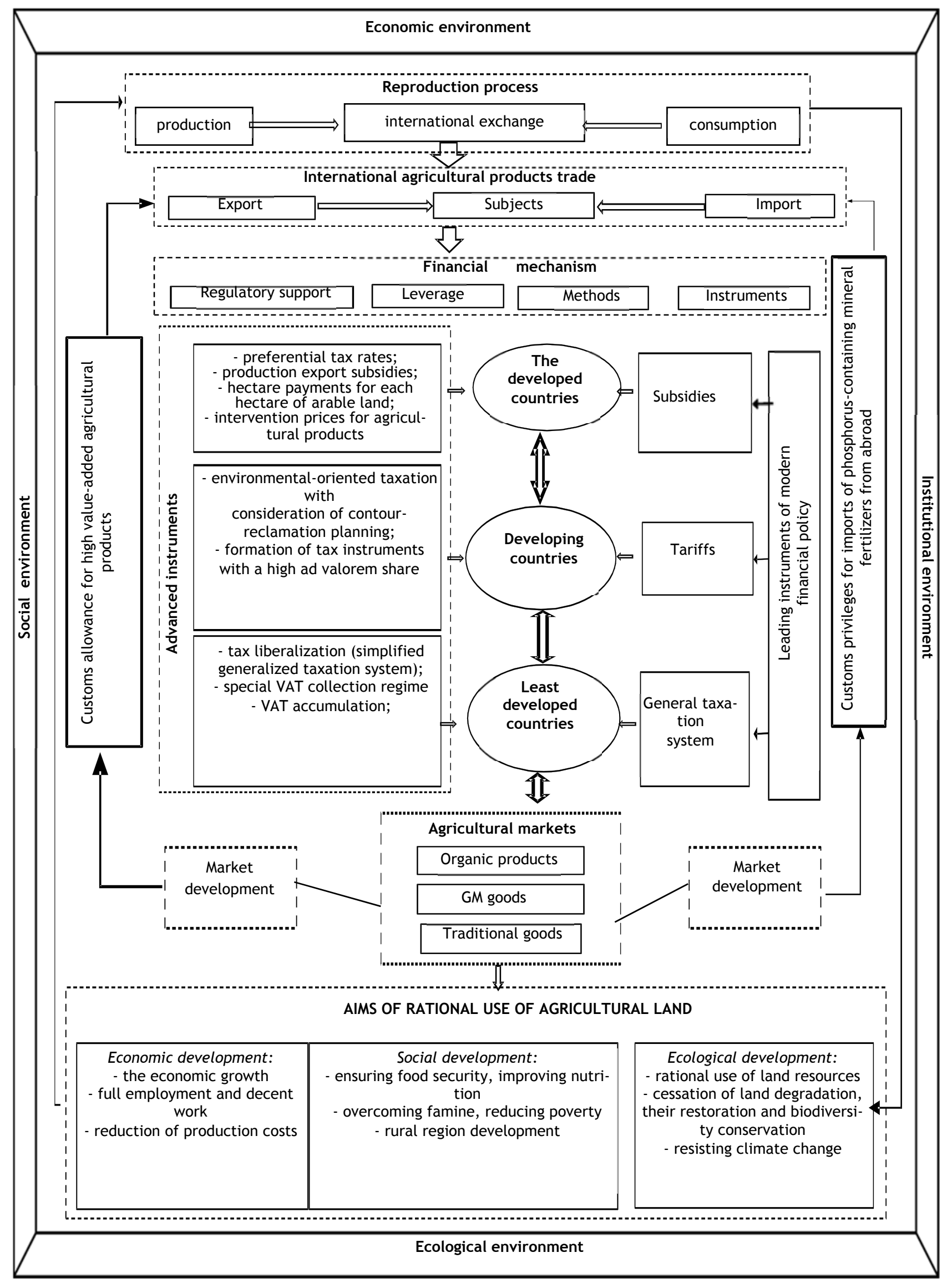

Figure. The concept of strengthening the role of the economic mechanism in the context of the rational use of agricultural land

Source: Formed by the author. 
Criteria and proposal for the taxation of sloping lands

\begin{tabular}{|c|c|c|c|}
\hline $\begin{array}{l}\text { The angle } \\
\text { of the land }\end{array}$ & $\begin{array}{l}\text { Slope lands in the } \\
\text { total national } \\
\text { land fund * }\end{array}$ & Criteria for land tax benefits & Tax concession (offer) \\
\hline 1 & 2 & 3 & 4 \\
\hline $1-3^{\circ}$ & $9,77 \mathrm{mln} . \mathrm{ha}$ & $\mathrm{N} / \mathrm{A}$ & $\mathrm{N} / \mathrm{A}$ \\
\hline $3-5^{\circ}$ & $2,5 \mathrm{mln} . \mathrm{ha}$ & Three-field crop rotation; & $20 \%$ land tax \\
\hline $5-7^{\circ}$ & $0,5 \mathrm{mln} . \mathrm{ha}$ & $\begin{array}{l}\text { Introduction of soil- } \\
\text { protective technologies; in- } \\
\text { crease in the area under } \\
\text { cover crops to } 45-50 \%\end{array}$ & $50 \%$ of land tax \\
\hline$>7^{\circ}$ & 85 million.ha & $\begin{array}{l}\text { The ban on the use of agri- } \\
\text { cultural land. The nursery of } \\
\text { fruit-medicinal trees. }\end{array}$ & $\begin{array}{l}\text { Exempt from taxation, if the land is } \\
\text { allocated under the nursery trees. }\end{array}$ \\
\hline
\end{tabular}

Source: Formed by the author, the distribution of arable land over the steep slopes, data from the State Land Committee of Ukraine as of 2010 [4].

Conclusions. The creation of the necessary prerequisites for the rational use and reproduction of land resources of land use is an extremely urgent problem of the modern socioeconomic and socio-political life of the country. Ukraine needs to refine the economic mechanism for the rational use of agricultural land, taking into account and preferring the tariff basis of taxation, which directs land users to comply with the ecological and economic crop rotation. Reduction of the level of plowed-up terri-

\section{Список бібліографічних посилань}

1. Андрушенко А. В. До питання виділення коштів для відновлення попереднього стану порушених земель. АгроcBim. 2010. № 24. C. 18-22.

2. Балюк С. А. Концептуальні засади економічного механізму відтворення родючості ґрунтів. Вісник аграрної науки. 2014. № 2. С. 60-65.

3. Борисова В. А. Відтворення природного ресурсного потенціалу АПК: економічні аспекти. Суми : Вид-во «Довкілля», 2003. 372 с.

4. Державна служба України з питань геодезії, картографії та кадастру: веб-сайт. URL : http://land.gov.ua/ru/ zemleustrii-ta-okhorona-zemel (дата звернення: 13.05.2019).

5. Добряк В. К., Бабміндра Д. І. Еколого-економічні засади реформування землекористування в ринкових умовах : монографія. Київ : Урожай, 2006. 336 с.

6. Заяць В. М. Реформа державного регулювання земельних відносин, як чинник становлення цивілізованого ринку земель. Теорія і практика ринків. 2008. № 1-2. С. 16-26

7. Кошкалда І. В. Ефективність використання сільськогосподарських земель у контексті сучасного господарювання. АгроІнКом. 2011. № 10. С. 38-43.

8. Кошкалда І. В. Подальший розвиток земельних відносин за умови використання світового досвіду. Вісник Білоцерківського державного аграрного університету. 2009. № 63. C.81-84.

9. Кошкалда І. В., Шелудько К. В. Агрохімічна паспортизація як передумова формування сталого сільськогосподарського землекористування. Економічний вісник універcumemy. 2018. № 39. C. 7-12.

10. Костишин O. О., Стойко Н. $\epsilon$. Економічний механізм регулювання землекористування в Україні. Науковий вісник Нлту України. 2013. Вип. 23.16. С. 248-254. tories and, at the same time, rationally using a more productive land fund with the introduction of intensive technologies on them.

Economic stimulation is at the stage of formation and the main prerequisite should be environmentally oriented differentiation of taxation, which takes into account the maximum organization in accordance with the scientifically based requirements of crop rotation and the criterion of nutrient changes and changes in the score of soil quality.

\section{References}

1. Andrushenko, A.V. (2010). Do pytannia vydilennia koshtiv dlia vidnovlennia poperednoho stanu porushenykh zemel [On the issue of allocating funds to restore the previous state of disturbed land]. Ahrosvit, 24, pp. 18-22 [In Ukrainian].

2. Baliuk, S.A. (2014). Kontseptualni zasady ekonomichnoho mekhanizmu vidtvorennia rodiuchosti gruntiv [Conceptual foundations of the economic mechanism of reproduction of soil fertility]. Visnyk ahrarnoi nauky, 2, pp. 60-65 [In Ukrainian].

3. Borysova, V.A. (2003). Vidtvorennya prirodnogo resursnogo potencialu APK: ekonomichni aspekti [Reproduction of the natural resource potential of the AIC: economic aspects: monograph]. Sumy: Vyd-vo "Dovkillia" [In Ukrainian].

4. Derzhavna sluzhba Ukrainy z pytanheodezii, kartohrafii ta kadastru [State Service of Ukraine for Geodesy, Cartography and Cadastre]: Retrieved from: http://land.gov.ua [In Ukrainian].

5. Dobriak, V.K. \& Babmindra, D.I. (2006). Ekolohoekonomichni zasady reformuvannia zemlekorystuvannia $v$ rynkovykh umovakh: monohrafiia [Ecological and economic principles of land use reform in market conditions: monograph]. Kyiv: Urozhai [In Ukrainian].

6. Zaiats, V.M. (2008). Reforma derzhavnoho rehuliuvannia zemelnykh vidnosyn yak chynnyk stanovlennia tsyvilizovanoho rynku zemel [Reform of state regulation of land relations as a factor in the establishment of civilized land market]. Teoriia i praktyka rynkiv, 1-2, pp. 16-26 [In Ukrainian].

7. Koshkalda, I.V. (2011). Efektyvnist vykorystannia silskohospodarskykh zemel u konteksti suchasnoho hospodariuvannia [Efficiency of agricultural land use in context of modern management]. AgrolnKom, 10, pp. 38-43 [In Ukrainian].

8. Koshkalda, I.V. (2009). Podalshyi rozvytok zemelnykh vidnosyn za umovy vykorystannia svitovoho dosvidu [Further development of land relations provided the use of world experience]. Visnyk Bilotserkivskoho derzhavnoho ahrarnoho universytetu, 63, pp. 81-84 [In Ukrainian]. 
11. Краснолуцький О. В., Тихенко Р. В., Євсюков Т. О. Складання проектів землеустрою, що забезпечують екологоекономічно обґрунтовані сівозміни та впорядкування угідь. Землевпорядний вісник. 2010. № 4. С. 14-17.

12. Мартинюк М. П. До питання економічного стимулювання раціонального використання й охорони земель. Науковий вісник Херсонського державного університету. 2016. Вип. 19. С. 120-123.

13. Методичні рекомендації щодо економічного стимулювання власників землі та землекористувачів за раціональне використання і охорону земель / Федоров М. М. та ін. Київ : ННЦ “ІАЕ”, 2010. 36 с.

14. Панас Р. М. Раціональне використання та охорона земель : навч. посіб. Львів : Новий Світ-2000, 2008. 349 с.

15. Про державний контроль за використанням та охороною земель : Закон України від 28 грудня 2015 року (зі змінами) № 963-IV. URL : https://zakon.rada.gov.ua/laws/show/ 963-15 (дата звернення: 13.02.2019).

16. Саблук П. Т., Лукінов І. І., Юрчишин В. В. Сучасна аграрна політика України: проблеми становлення : монографія. Київ : ННЦ«|АЕ», 1996. 664 с.

17. Сологуб Ю. І, Андрющенко А. М. Перспективи альтернативного землеробства в Україні. Агробізнес. 2002. № 11(13). С. 53-60.

18. Стратегічні напрями розвитку сільського господарства України на період до 2020 року / за ред. Ю. О. Лупенка, В. Я. Месель-Веселяка. Київ : ННЦ “ІАЕ”, 2012. 182 с.

19. Трегобчук В. М. Відтворення та ефективне використання ресурсного потенціалу АПК (теоретичні та практичні аспекти) : монографія. Київ : ННЦ «ІАЕ», 2003. 259 с.

20. Третяк А. М. Стратегія реформування земельної політики в Україні на сучасному етапі. Землевпорядний вісник. 2009. № 6. С. 12-21.

21. Федоров М. М. Економічні проблеми земельних відносин у сільському господарстві : монографія. Київ : ННЦ «IAE», 1998. 263 c.

22. Matthews A. Greening CAP payments. A missed opportunity? Institute for International and European Affairs. Dublin. 2013. Pp.1-14.

23. Hong Li, Zhenxing Xiong. Resource tax reform and economic structure transition of resource-based economies. Resources, Conservation and Recycling, 136. 2018. Pp. 389-398 [In English].

24. Marian Sling. The Principle of Rational Use of Natural Resources in the Theory of Optimal Planning Eastern European Economics Vol. 16, No. 4 (Summer, 1978). Pp. 3-23 [In English].

25. European Parliament resolution of 8 July 2010 on the future of the Common Agricultural Policy after 2013. URL : http: / /www.europarl.europa.eu.

26. Williamson I., Enemark S., Wallace J. Land administration for sustainable development California: Esri press, 2010. $487 \mathrm{p}$.
9. Koshkalda, I.V. \& Sheludko, K.V. (2018). Ahrokhimichna pasportyzatsiia yak peredumova formuvannia staloho silskohospodarskoho zemlekorystuvannia [Agrochemical certification as a prerequisite for the formation of sustainable agricultural land use]. Ekonomichnyi visnyk universytetu, 39, pp. 7-12 [In Ukrainian].

10. Kostyshyn, O.O. \& Stoiko, N.Ye. (2013). Ekonomichnyi mekhanizm rehuliuvannia zemlekorystuvannia $v$ Ukraini [The economic mechanism of regulation of land use in Ukraine]. Naukovyj visnyk NLTU Ukrainy, 23.16, pp. 248-254 [In Ukrainian].

11. Krasnolutskyi, O.V., Tyhenko, R.V., \& Yevsiukov, T.O. (2010). Skladannya proektiv zemleustroyu, sho zabezpechuyut ekologo-ekonomichnoobgruntovani sivozmini ta vporyadkuvannya ugid [Drafting of land management projects that provide ecologically-economically justified crop rotations and landscaping]. Zemlevporyadnij visnik, 4, pp. 14-17 [In Ukrainian].

12. Martyniuk, M.P. (2016). Do pytannia ekonomichnoho stymuliuvannia ratsionalnoho vykorystannia y okhorony zemel [On the issue of economic incentives for rational use and protection of land]. Naukovyi visnyk Khersonskoho derzhavnoho universytetu, 19, pp. 120-123 [In Ukrainian].

13. Fedorov, M.M., Khodakivska, O.V., et al. (2010). Metodychni rekomendatsii shchodo ekonomichnoho stymuliuvannia vlasnykiv zemli ta zemlekorystuvachiv za ratsionalne vykorystannia i okhoronu zemel [Methodical recommendations on economic stimulation of land owners and land users for rational use and protection of land]. Kyiv: NNS "IAE" [In Ukrainian].

14. Panas, R.M. (2008). Ratsionalne vykorystannia ta okhorona zemel: navch. posib [Rational use and protection of land: tutorial]. Lviv: Novyi Svit-2000 [In Ukrainian].

15. Pro derzhavnyi control za vykorystanniam ta okhoronoiu zemel: Zakon Ukrainy vid 28.12.2015 roku №963-IV (zi zminamy) [On state control over the use and protection of lands: Law of Ukraine dated 28.12.2015, No. 963-IV]. Zakon Rada. VR Ukrainy. Retrieved from: https://zakon.rada.gov.ua [In Ukrainian].

16. Sabluk, P.T., Lukinov, I.I., \& Yurchyshyn, V.V. (1996). Suchasna ahrarna polityka Ukrainy: problem stanovlennia [Modern agrarian policy of Ukraine: problems of formation: monograph]. Kyiv: NNTs "IAE" [In Ukrainian].

17. Solohub, Yu.l. \& Andriushchenko, A.M. (2002). Perspektyvy alternatyvnoho zemlerobstva $\vee$ Ukraini [Prospects for alternative agriculture in Ukraine]. Ahrobiznes, 11 (13), pp. 5360 [In Ukrainian]

18. Lupenko, Yu.O., Mesel-Veseliak, V.Ya., Khodakivska, O.V., et al. (2012). Stratehichni napriamy rozvytku silskoho hospodarstva Ukrainy na period do 2020 roku [The strategic directions of development of agriculture of Ukraine till 2020]. Kyiv: NNTs “IAE" [In Ukrainian].

19. Trehobchuk, V.M. (2003). Vidtvorennia ta efektyvne vykorystannia resursnoho potentsialu APK (teoretychni ta praktychni aspekty): monohrafiia [Reproduction and effective use of the resource potential of the agroindustrial complex (theoretical and practical aspects): monograph]. Kyiv: NNTs “IAE" [In Ukrainian].

20. Tretiak, A.M. (2009). Stratehiia reformuvanva zemelnoi polityky $v$ Ukraini na suchasnomu etapi [The strategy of reforming land policy in Ukraine at the present stage]. Zemlevporiadnyi visnyk, 6, pp. 12-21 [In Ukrainian].

21. Fedorov, M.M. (1998). Ekonomichni problemy zemelnykh vidnosyn u silskomu hospodarstvi: monohrafiia [Economic problems of land relations in agriculture: monograph]. Kyiv: NNTs "IAE" [In Ukrainian].

22. Matthews, A. (2013). Greening CAP payments. A missed opportunity? (pp. 1-14). Dublin: Institute for International and European Affairs [In English].

23. Hong, L. \& Zhenxing, X. (2018). Resource tax reform and economic structure transition of resource-based economies. Resources, Conservation and Recycling, 136, pp. 389-398 [In English].

24. Sling, M. (1978). The principle of rational use of natural resources in the theory of optimal planning. Eastern European Economics, Vol. 16, No. 4, pp. 3-23 [In English].

25. On the future of the Common Agricultural Policy after 2013: Resolution of the European Parliament dated 8.07.2010. European Parliament. Retrieved from: http: / /www.europarl.europa.eu [In English].

26. Williamson, I., Enemark, S., \& Wallace, J. (2010). Land administration for sustainable development. California: Esri press [In English]. 


\section{Крамарьов О.С. Економічне стимулювання раціонального використання сільськогосподарських земель}

Mета cmammi - дослідити особливості та необхідні передумови економічного стимулювання раціонального використання сільськогосподарських земель.

Методика дослідження. Застосовано методи: статистико-економічний (при розрахунках площі земель із різною схиловою крутизною), порівняльний, розрахунковий. На основі абстрактно-логічного, системного й порівняльних аналізів згруповано інструменти, що притаманні сучасним фінансовим політикам для країн різного економічного розвитку у формуванні економічного механізму раціонального використання сільськогосподарських земель. Структуризація основних фінансових інструментів й напрями їх вдосконалення здійсненна з використанням графічного методу та системного niдxодy.

Результати дослідження. У процесі вивчення висвітлено особливості застосування економічного стимулювання раціонального використання земель сільськогосподарського призначення. Проаналізовано основні передумови для раціонального використання та відтворення земельних ресурсів.

Елементи наукової новизни. Визначено поняття «економічне стимулювання раціонального землекористування», системне вивчення якого створює методологічну основу для обґрунтування та імплементації цілісної системи забезпечення раціонального використання земель сільськогосподарського призначення.

Практична значущість. Обґрунтовано пропозиції щодо економічного стимулювання раціонального використання земель сільськогосподарського призначення, запропоновано критерії й рекомендації щодо оподаткування схилових земель. Табл.: 1. Рис.: 1. Бібліогр.: 26.

Ключові слова: раціональне землекористування; економічне стимулювання; земельні ресурси; підвищення родючості угідь; охорона земель; податкові пільги.

Крамарьов Олександр Сергійович - науковий співробітник лабораторії економічних досліджень, Державна установа «Інститут зернових культур НААН» (м. Дніпро, вул. В. Вернадського, 14)

E-mail: askramar@ukr.net

ORCID iD http://orcid.org/0000-0002-0350-6213

\section{Крамарёв А.С. Экономическое стимулирование рационального использования сельскохозяйственных земель}

Цель статьи - исследовать особенности и необходимые предпосылки экономического стимулирования рационального использования сельскохозяйственных земель.

Методика исследования. Использованы методы: статистико-экономический (при расчетах площадей земель с различной склоновой крутизной), сравнительный, расчетный. На основе абстрактно-логического, системного и сравнительных анализов сгруппированы инструменты, присущие современным финансовым политикам для стран разного экономического развития в формировании экономического механизма рационального использования сельскохозяйственных земель. Структуризация основных финансовых инструментов и направления их совершенствования осуществлена с использованием графического метода и системного подхода.

Результаты исследования. В процессе изучения освещены особенности применения экономического стимулирования рационального использования земель сельскохозяйственного назначения. Проанализированы основные предпосылки для рационального использования и воспроизводства земельных ресурсов.

Элементы научной новизны. Определено понятие «экономическое стимулирование рационального землепользования», системное изучение которого создает методологическую основу для обоснования и имплементации целостной системы обеспечения рационального использования земель сельскохозяйственного назначения.

Практическая значимость. Обоснованы предложения по экономическому стимулированию рационального использования земель сельскохозяйственного назначения, предложены критерии и рекомендации по налогообложению склоновых земель. Табл.: 1. Илл.: 1. Библиогр.: 26.

Ключевые слова: рациональное землепользование; экономическое стимулирование; земельные ресурсы; повышение плодородия угодий; охрана земель; налоговые льготы.

Крамарев Александр Сергеевич - научный сотрудник лаборатории экономических исследований, Государственное учреждение «Институт зерновых культур НАAН» (г. Днепр, ул. Вернадского, 14)

E-mail: askramar@ukr.net

ORCID iD http://orcid.org/0000-0002-0350-6213

The article has been received 01.07.2019

Revision: 15.07.2019

Бібліографічний опис для цитування:

Kramarov O. S. Economic incentives for the rational use of agricultural land. Економіка АПК. 2019. № 7. C. $92-100$. 